\title{
CIRCLING BACK
}

\section{CYMENE HOWE}

(D) http: / / orcid.org/0000-0002-9361-3812

JAMES FAUBION

(D) http: / / orcid.org/0000-0003-0847-3008

\section{DOMINIC BOYER}

(D) http: / / orcid.org/0000-0001-8944-406X

Rice University

The editors' introduction to our first issue as editors of Cultural Anthropology proclaimed that our mission was to create circles, not pyramids (Boyer, Faubion, and Howe 2015). Back then, Donald Trump was still only the stuff of reality TV and tabloid journalism. Our city of Houston was not yet infamous for new rainfall measurement codes on weather maps, before a slow hurricane named Harvey dumped four feet of rain across too much asphalt and sprawl. But since beginning our work with the journal, we've also seen a great resurgence in unapologetic activism through movements like \#BlackLivesMatter (Williams 2015), Standing Rock (Dhillon and Estes 2016), and \#MeToo (West 2018). This gives us hope. When we embarked on this collective trip as editors, we were looking for essays that produced the unexpected, that were timely and also untimely. In that ecumenical spirit we announced: "Send us the best there is and we will publish it!" You did. And we did, with a vision of decentralizing authority and responsibility as our guide. 
Over the last five years we have seen brilliant refractions in the work that has come across our screens. Truly exciting conversations continue to bloom in cultural anthropology, from the infrastructural to the Anthropocenic, from the ethics of care to the politics of movement, and from humanitarianisms to the more-than-human, to name a few. The many scholars whose manuscripts we read taught us an immense amount about the current direction of a field that continues to grow and overflow in its ambitions - reflecting an epistemic ecology that is both lush and weedy, often crowned with vivid theoretical petals but still rooted in an earthy empirical sensibility. We found the discipline less divided into insular and antagonistic camps, less fragmented than we might have predicted. Anthropological thinking today, we discovered, is not preoccupied with recursion but instead fascinated with serial processes of emergence and uncertainty. These are speculative times where, with a nod to Paul Rabinow, an anthropology of the contemporary is reinventing itself. But this is not to the exclusion of recognizing the deeply political acts of documenting and narrating human (and other) lifeways and worlds. Our field continues to hold promise and surprise and, certainly, the power to anticipate.

During our tenure as editors, we were able to send out an unprecedented number of submissions for review and we depended on the recommendations of our editorial board in soliciting reviewers. That board was also constituted so as to include scholars whose specialties were not our own and whose networks had global reach. Without the sage advice of the editorial board and the stellar work done by reviewers, the journal could not have been realized. The energy and commitment of our contributing editors - early-career scholars from many different institutions - buoyed our spirits always. Their generosity of time and intelligence is unsurpassed, and we are pleased to have their work online, free for the entire world to use and appreciate, in sections of the Cultural Anthropology website such as AnthroPod, Teaching Tools, and the Visual and New Media Review. Our editorial assistant, Jessica Lockrem, and our managing editor, Marcel LaFlamme, have been absolutely fabulous, perhaps even flawless - as anyone who has worked with either of them will know. Thank you all. Thank you for your care and labor and commitment to this collective project of journal-making. We look forward to the day when some of you become the editors of Cultural Anthropology.

Our work as anthropologists is lively and animated, full of voice and sounds and scenes and smells. To stay true to that ethnographic experience, we were glad to be able to shepherd a new feature of the journal that we call Sound + 
Vision (see Boyer et al. 2016). We launched Sound + Vision with three stunning, multimediated essays/soundscapes/encounters: "Gravity's Reverb" (Helmreich 2016), "The Infinite Rounds of the Stubborn" (Thorkelson 2016), and "The Golden Snail Opera” (Tsai et al. 2016). A handful of other contributions have appeared since then, and we expect this new modality of exposition - the first of its kind in an anthropology journal - to burgeon in the years to come. Sound + Vision is, we think, a glimpse into the future of anthropological communication, and one that is good to teach with as well.

On the textual side, we were able to inaugurate Openings and Retrospectives, a section of the journal that bundles three to five conceptually driven essays to focus on a particular thematic. This was meant to reconfigure the special issue form and to encourage shorter pieces with theoretical heft. Retrospectives have provided commentary on debates in the field including sovereignty (Kauanui 2017), affect (White 2017), and queer anthropology (Manalansan 2016), seeking to reflect on a mature set of interventions while also pitching them in new directions. Openings collections, concerning phenomena like algorithms (Lowrie 2018), chemo-ethnography (Shapiro and Kirksey 2017), and life above earth (Howe 2015), among others, have been dedicated to emergent thematics: an invitation to imagine what anthropologists will be talking about next.

In all of our thinking about the journal's content, we have also been attuned to the inequalities that continue to exist in authorship and citational practices. We became keenly attentive to bibliographic gaps and we worked with authors to ensure that theoretical contributions by female scholars, scholars of color, and scholars from the global South were included in the citational repertoire of the articles we published. The politics of citation and authorship are not inconsequential to the success of careers, and we recognized that male authors (usually from the global North) often accrue more citational recognition and thus legitimacy, particularly in the domain of theory; this is what Sara Ahmed (2014) calls "the citational relational" (see also Strong et al. n.d.). We believe there is room to grow here too. Our August 2016 issue was the first in the history of Cultural Anthropology to be comprised of all female authors. Although this is an outcome that we could have engineered, in fact we did not. The composition of the issue came together organically out of the good work that came our way. We were equally pleased to be able to publish a significant number of articles by authors based outside of the global North. The circle, unlike the pyramid, seems to lend itself to expanding without collapsing; its slopes and curves have proven a splendid 
shape to replicate in our work as editors. A circle is also like a wheel, something to move us forward.

Now, we turn the keys over to an amazing new team of editors, Brad Weiss, Heather Paxson, and Christopher Nelson. As you enjoy the ride, please picture us rolling.

\section{REFERENCES}

Ahmed, Sara

2014 “White Men.” Feminist Killjoys, November 4. https://feministkilljoys.com/ 2014/11/04/white-men.

Boyer, Dominic, James Faubion, and Cymene Howe

2015 “Editors' Introduction to 30.1: Circles Not Pyramids." Cultural Anthropology 30, no. 1: 1-5. https://doi.org/10.14506/ca30.1.01.

Boyer, Dominic, James Faubion, Cymene Howe, and Marcel LaFlamme

2016 "Sound + Vision: Experimenting with the Anthropological Research Article of the Future." Cultural Anthropology 31, no. 4: 459-63. https://doi.org/ 10.14506/ca31.4.01.

Dhillon, Jaskiran, and Nick Estes, eds.

2016 "Standing Rock, \#NoDAPL, and Mni Wiconi." Hot Spots series, Cultural Anthropology website, December 22. https://culanth.org/fieldsights/1010-

Helmreich, Stefan standing-rock-nodapl-and-mni-wiconi.

2016 "Gravity's Reverb: Listening to Space-Time, or Articulating the Sounds of Gravitational-Wave Detection." Cultural Anthropology 31, no. 4: 464-92. https://doi.org/10.14506/ca31.4.02.

Howe, Cymene

2015 "Life Above Earth: An Introduction.” Cultural Anthropology 30, no. 2: 203-209. https://doi.org/10.14506/ca30.2.03.

Kauanui, J. Kēhaulani

2017 "Sovereignty: An Introduction." Cultural Anthropology 32, no. 3: 323-29. https://doi.org/10.14506/ca32.3.01.

Lowrie, Ian

2018 “Algorithms and Automation: An Introduction.” Cultural Anthropology 33, no. 3: 349-59. https://doi.org/10.14506/ca33.3.01.

Manalansan, Martin F., IV

2016 “Queer Anthropology: An Introduction." Cultural Anthropology 31, no. 4: 59597. https://doi.org/10.14506/ca31.4.07.

Shapiro, Nicholas, and Eben Kirksey

2017 "Chemo-Ethnography: An Introduction." Cultural Anthropology 32, no. 4: 48193. https://doi.org/10.14506/ca32.4.01.

Strong, Susan, Catherine Lutz, Jessica Katzenstein, and Amy Teller

n.d. "Gender and Citation in Cultural Anthropology." Unpublished manuscript.

Thorkelson, Eli

2016 "The Infinite Rounds of the Stubborn: Reparative Futures at a French Political Protest." Cultural Anthropology 31, no. 4: 493-519. https://doi.org/10.14506/ ca31.4.03.

Tsai, Yen-Ling, Isabelle Carbonell, Joelle Chevrier, and Anna Lowenhaupt Tsing

2016 "Golden Snail Opera: The More-than-Human Performance of Friendly Farming on Taiwan's Lanyang Plain.” Cultural Anthropology 31, no. 4: 520-44. https:// doi.org/10.14506/ca31.4.04. 
West, Paige, ed.

2018 "From Reciprocity to Relationality: Anthropological Possibilities." Hot Spots series, Cultural Anthropology website, September 26. https://culanth.org/

White, Daniel fieldsights / 1525 -from-reciprocity-to-relationality-anthropological-possibilities.

2017 “Affect: An Introduction." Cultural Anthropology 32, no. 2: 175-80. https:// doi.org/10.14506/ca32.2.01.

Williams, Bianca C., ed.

2015 “\#BlackLivesMatter: Anti-Black Racism, Police Violence, and Resistance." Hot Spots series, Cultural Anthropology website, June 29. https://culanth.org/ fieldsights/696-blacklivesmatter-anti-black-racism-police-violence-andresistance. 